\title{
Evaluation of Some Sugar Beet Varieties Under Sabahia and Nubaria Regions Conditions
}

\author{
Amr M. EI-Sheikh ${ }^{1}$, Nadia K. EI-Safy ${ }^{2}$, Hossam M. El-Sharnoby ${ }^{2}$ \\ ${ }^{1}$ Breed and genetic Dept., Sugar Crops Research Inst., ARC, Egypt. \\ ${ }^{2}$ Plant physiology and Chemistry Dept., Sugar Crops Research Inst., ARC, Egypt.
}

\begin{abstract}
Two field experiments were carried out at Sabahia, and Nubaria regions during $2016 / 2017$ and $2017 / 2018$ seasons, to evaluate ten varieties of sugar beet under Sabahia and Nubaria conditions. The experiments were conducted in split plot design with three replications, where the main plots assigned by the two location (Sabahia and Nubaria), while the sub plots were occupied by the ten varieties of sugar beet (Charelston (V1), Gazella (V2), Heba (V3), Lilly (V4), Mammut (V5), Matros (V6), Nancy (V7), Oscarpoly (V8), Puma (V9), and Pyramidia (V10). The results revealed that there was significant difference between the two locations and the cultivated verieties for most of studied characters, whereas planted each of Pyramidia, Puma and Oscarpoly under Nubaria and Sabahia region getting the highest yield, yield components and quality of sugar beet crop. Other cultivars under this study could be employed as other sugar beet genetic resources with reasonable root and sugar yields in such sandy soil of the Nubaria region.
\end{abstract}

Keywords: Sugar beet, varieties, Sabahia, Nubaria, region.

\section{INTRODUCTION}

Sugar beet became the main source of sugar production in Egypt. Varieties and region conditions considered as main factors for sugar production from sugar beet. Improving sugar beet yield and quality are the main goals of the governmental policy to increase sugar production in order to gradually cover the gap between sugar consumption and production through sowing the suitable variety under suitable conditions (FAO, 2016).

Many searchers revealed the importance of selected suitable varieties for increasing sugar yield as well as reported the differences between sugar beet varieties in yield and quality. Like Khan et al. (2004) found that sugar beet varieties differed significantly for yield and sugar contents. Gobarah and Mekki (2005) reported that the three sugar beet varieties i.e. Ras Ploy, Kawemira and Top were significantly different in root length and diameter, root weight, root yield, top yield, and sugar yields. Top cultivar showed more root, sugar yields than the other two cultivars, while the cultivar Ras Ploy showed more sucrose than Kawemira and Top cvs. This means that Ras Poly cultivar had the lowest $\mathrm{Na}, \mathrm{K}$ and $\alpha$-amino- $\mathrm{N}$ in their root juice. However, Nasr and Abd El-Razek (2008) evaluated 6 exotic sugar beet cultivars under newly reclaimed soil condition of Sinai and they revealed that the cultivar Oscar poly gave the highest root yield but, Monte Bianco cultivar surpassed all cultivars in sugar yield. Also, Korayem et al. (2012) observed that ten sugar beet cultivars differed in yield and quality. Hozayn et al. (2013) stated that exotic sugar beet varieties should be undertaken on yield and sugar quality traits. The cultivar Heliospoly, proved to be the best promising cultivar with the highest root yield, sugar recovery and ultimate maximum sugar yield can be planted as 
commercial crop at Nubaria region. Conversely, Monte Rosa comes out as a poorest cultivar with minimum root yield and eventually provided lowest sugar yield. Other cultivars could be employed as other sugar beet genetic resources with reasonable root and sugar yields in such Nubaria conditions. Also, Mohamed and Yasin (2013) reported that the differences among the varieties i.e. Panther, Des 9003, LP15 and Sibel were significant in yield, its components and quality. On the other hand, the difference between monogerm varieties Des 9003 and LP15, and also multigerm beet varieties don't reach the significant level for root diameter.

The aim of this study is to evaluate ten sugar beet varieties under two locations in Egypt i.e. Sabahia and Nubaria conditions.

\section{MATERIALS AND METHODS}

Two field experiments were carried out at Sabhia and Nubaria, Egypt during $2016 / 2017$ and $2017 / 2018$ seasons, to evaluate ten varieties of sugar beet (Beta vulgaris $L$.) under the two cultivated regions.

The preceding summer crop was maize (Zea mays L.) in both seasons. Before planting, soil samples were randomly taken from the experimental site at a depth of 0 to $30 \mathrm{~cm}$ from soil surface and prepared for chemical analysis according to Chapman and Pratt (1978) which presented in Table (1).

The soil of field experiments was prepared through two ploughing and leveling. Nitrogen fertilizer was added at a rate of $90 \mathrm{~kg} \mathrm{~N} / \mathrm{fed}$ after thinning and before the second irrigation time after sowing, Calcium super phosphate $(15.5 \%$ $\mathrm{P}_{2} \mathrm{O}_{5}$ ) was applied during tillage operation at rate of $100 \mathrm{~kg} \mathrm{P}_{2} \mathrm{O}_{5} / \mathrm{fed}$. Potassium sulfate $\left(48 \% \mathrm{~K}_{2} \mathrm{O}\right)$ was applied at the rate of $24 \mathrm{~kg} \mathrm{~K}_{2} \mathrm{O} / \mathrm{fed}$ with the first irrigation. Plants were kept free from weeds, which were manually controlled by hand hoeing at three times. The common agricultural practices for growing sugar beet were followed according to the recommendations of Ministry of Agriculture except the factors under study.

Sugar beet varieties (Charelston V1, Gazella V2, Heba V3, Lilly V4, Mammut V5, Matros V6, Nancy V7, Oscarpoly V8, Puma V9, and PyramidiaV10) were obtained from Sugar Crop Research Institute, Agricultural Research Center, Giza. Seeds were hand sown as the usual dry sowing on one side of the ridge in hills $25 \mathrm{~cm}$ apart at the rate of $4-5$ seed ball per hill and sown at $9^{\text {th }}$ and $12^{\text {th }}$ October, respectively and harvested after 200 days

The experimental design was split plot design with three replications, each experimental basic unit was $10.5 \mathrm{~m}^{2}$ included 5 ridges, $60 \mathrm{~cm}$ apart and $3.5 \mathrm{~m}$ long. The main plots were occupied by the two locations (Sabahia and Nubaria); while the sub plots units were assigned by the ten sugar beet variety.

Average of climate data at Nubaria and Sabhia regions in Alexandria during 2016/2017 and 2017/2018 seasons are shown in Table (2 and 3 ). 
Table (1). Some physical and chemical properties of the experimental soil sites

\begin{tabular}{|c|c|c|}
\hline \multicolumn{3}{|c|}{ Region } \\
\hline Soil properties & Sabahia & Nubaria \\
\hline A- Mechanical analysis & & \\
\hline Clay \% & 43.6 & 18.0 \\
\hline Silt $\%$ & 44.7 & 24.2 \\
\hline Sand \% & 12.1 & 57.8 \\
\hline Textural class & Clay loam & Sandy loam \\
\hline B- Chemical analysis & & \\
\hline $\mathrm{pH}$ & 8.1 & 8.3 \\
\hline $\mathrm{EC}(\mathrm{dS} / \mathrm{m})$ & 2.9 & 1.8 \\
\hline Soluble anions (meq/l) & & \\
\hline $\mathrm{HCO}_{3}^{-}$ & 1.8 & 1.22 \\
\hline $\mathrm{Cl}^{-}$ & 24.6 & 25.0 \\
\hline $\mathrm{SO}_{4}^{--}$ & 1.7 & 2.0 \\
\hline Soluble cations (meq/l) & & \\
\hline $\mathrm{Ca}^{++}$ & 6.0 & 4.9 \\
\hline $\mathrm{Mg}^{++}$ & 6.2 & 5.9 \\
\hline $\mathrm{Na}^{+}$ & 13.6 & 12.4 \\
\hline $\mathrm{K}^{+}$ & 1.5 & 1.6 \\
\hline Available nitrogen $(\mathrm{mg} / \mathrm{kg})$ & 23.00 & 23.10 \\
\hline Organic matter (\%) & 0.45 & 0.27 \\
\hline
\end{tabular}

Plant weight $(\mathrm{g})$, root weight $(\mathrm{g})$, root diameter $(\mathrm{cm})$, root yield $(\mathrm{t} / \mathrm{fed})$, top yield ( $t / f e d)$, sugar yield (t/fed), TSS (\%) as well as sucrose (\%) were studied. Where, TSS and sucrose percentage estimated in fresh samples of sugar beet root by using Saccharometer according to the method described by AOAC (1995).

All obtained data were statistically analyzed according to the technique of analysis of variance (ANOVA) for the split plot design as published by Gomez and Gomez (1984). Least Significant Difference (LSD) method was used to test the differences between treatment means at $5 \%$ level of probability. Correlations of the traits obtained from the experiment were computed using Costat program. All the statistical analyses were performed using CoStat V 6.4 (2005) for Windows. 
J. Adv. Agric. Res. (Fac. Agric. Saba Basha)

Table (2). Average of climate data in Nubaria region, Al-Buhaira from October to April during 2016/2017 and 2017/2018 seasons

\begin{tabular}{|c|c|c|c|c|c|c|c|c|c|c|c|c|c|c|}
\hline \multirow{2}{*}{ Variable } & \multicolumn{7}{|c|}{$2016 / 2017$} & \multicolumn{7}{|c|}{ 2017/2018 } \\
\hline & October & November & December & January & February & March & April & October & November & December & January & February & March & April \\
\hline Temp. maximum $\left({ }^{\circ} \mathrm{C}\right)$ & 22.9 & 21.4 & 15.8 & 14.6 & 22.4 & 23.7 & 27.7 & 33.4 & 26.5 & 24.4 & 17.3 & 17.2 & 26.7 & 29.6 \\
\hline Temp. min. $\left({ }^{\circ} \mathrm{C}\right)$ & 18.1 & 14.1 & 8.4 & 7.8 & 9.5 & 12.00 & 13.8 & 15.0 & 10.4 & 9.6 & 12.6 & 14.0 & 9.1 & 9.7 \\
\hline Temp. average $\left({ }^{\circ} \mathrm{C}\right)$ & 20.17 & 1 & 11.57 & 10.85 & 15.5 & 17.29 & 20.47 & 22.5 & 18.3 & 17 & 14.9 & 15.6 & 17.6 & 18.8 \\
\hline Dew Point & 5.8 & 8.8 & 2.93 & 2.56 & 2.00 & 1.66 & 10.6 & 24.9 & 14.0 & 12.7 & 10.9 & 12.6 & 12.1 & 13.8 \\
\hline Relative humidity (\%) & 65.1 & 73.2 & 78.0 & 65.1 & 63.8 & 64.15 & 61.00 & 73 & 77.5 & 77.1 & 72.0 & $79 \%$ & 72.8 & 74.9 \\
\hline Wind speed $(\mathrm{km} / \mathrm{h})$ & 10.7 & 3.4 & 3.21 & 3.29 & 5.6 & 2.33 & 5.61 & 5.8 & 14.8 & 1.1 & 4.0 & 4.7 & 8.9 & 10.6 \\
\hline Wind Gust (km/h) & 19.6 & 19.2 & 4.7 & 7.9 & 7.4 & 24.6 & 24.1 & 19.8 & 19.8 & 19.8 & 2.9 & 7.9 & 24.1 & 24.1 \\
\hline Wind direction & SE & SE & SSE & ESE & ESE & East & East & SE & SE & SSE & ESE & ESE & East & East \\
\hline Precipitation $(\mathrm{mm})$ & 2.3 & 2.66 & 3.0 & 8.00 & 2.3 & 8.5 & 1.5 & 11.7 & 1.3 & 0 & 12.30 & 0 & 0.3 & 0.5 \\
\hline $\begin{array}{l}\text { Possible sunshine } \\
\text { duration (hr) }\end{array}$ & 10.52 & 10.27 & 11.2 & 12.0 & 12.0 & 10.00 & 10.25 & 10.60 & 10.27 & 10.97 & 11.83 & 12.80 & 14.60 & 10.00 \\
\hline Pressure (hpa) & 1012.2 & 1009.8 & 1006.1 & 1011.3 & 1015.3 & 1013.8 & 1012.4 & 1018.5 & 1023.9 & 1026.3 & 1015 & 1011.7 & 1017.8 & 1017.5 \\
\hline
\end{tabular}

Table (3). Average of climate data in Sabahia region, Alexandria from October to April during 2016/2017 and 2017/2018 seasons

\begin{tabular}{|c|c|c|c|c|c|c|c|c|c|c|c|c|c|c|}
\hline \multirow{2}{*}{ Variable } & \multicolumn{7}{|c|}{$2016 / 2017$} & \multicolumn{7}{|c|}{$2017 / 2018$} \\
\hline & October & November & December & January & February & March & April & October & November & December & January & February & March & April \\
\hline Temp. maximum $\left({ }^{\circ} \mathrm{C}\right)$ & 30.3 & 24.0 & 19.1 & 13.2 & 18.3 & 19.5 & 20.8 & 27.8 & 24.4 & 17.8 & 16.7 & 20.0 & 21.1 & 23.9 \\
\hline Temp. min. $\left({ }^{\circ} \mathrm{C}\right)$ & 23.1 & 18.3 & 13.6 & 10.31 & 9.7 & 9.1 & 12.4 & 24.4 & 21.6 & 14.4 & 12.2 & 14.4 & 13.3 & 19.4 \\
\hline Temp. average $\left({ }^{\circ} \mathrm{C}\right)$ & 27.0 & 21.1 & 16.2 & 11.61 & 13.28 & 14.39 & 16.61 & 26.10 & 22.5 & 16.1 & 14.4 & 17.2 & 17.2 & 21.7 \\
\hline Dew Point & 18.1 & 15.3 & 11.6 & 14.2 & 11 & 10.6 & 11.8 & 11.1 & 14.0 & 10.7 & 8.9 & 10.6 & 9.1 & 11.8 \\
\hline Relative humidity (\%) & 73.0 & 77.4 & 77.2 & 70 & 73 & 67 & 66 & 73 & 77.5 & 77.1 & 72.0 & $79 \%$ & 72.8 & 74.9 \\
\hline Wind speed $(\mathrm{km} / \mathrm{h})$ & 4.0 & 9.8 & 5.3 & 3.22 & 3.32 & 5.9 & 5.6 & 5.8 & 8.8 & 1.1 & 3.0 & 5.7 & 6.9 & 7.6 \\
\hline Wind Gust $(\mathrm{km} / \mathrm{h})$ & 19.8 & 19.8 & 19.8 & 13.4 & 10.23 & 20.15 & 7.9 & 19.8 & 19.8 & 19.8 & 2.9 & 7.9 & 24.1 & 24.1 \\
\hline Wind direction & SE & SE & SSE & ESE & ESE & East & East & SE & SE & SSE & ESE & ESE & East & East \\
\hline Precipitation (mm) & 2.1 & 2.8 & 3.1 & 8.0 & 1.56 & 11.3 & 8.02 & 2.7 & 2.0 & 3.0 & 9.5 & 8.0 & 2.3 & 2.3 \\
\hline $\begin{array}{l}\text { Possible sunshine } \\
\text { duration (hr) }\end{array}$ & 8.60 & 10.20 & 10.14 & 12 & 12.1 & 12 & 11.4 & 9.60 & 10.20 & 11.0 & 12.0 & 12.0 & 14.3 & 11.1 \\
\hline Pressure (hpa) & 1014.1 & 1018.0 & 1013.3 & 1016.1 & 1015.2 & 1014.0 & 1012.2 & 1010.5 & 1009.9 & 1006.3 & 1010.0 & 1012.7 & 1013.8 & 1015.5 \\
\hline
\end{tabular}




\section{RESULTS AND DISCUSSIONS}

Results presented in Table (4) showed the effect of sugar beet varieties, locations and their interaction on plant weight $(\mathrm{g})$, root weight $(\mathrm{g}) / \mathrm{plant}$ and root length (cm) during 2016/2017 and 2017/2018 seasons.

In respect to effect of the two locations, the results indicated that planting sugar beet under Nubaria conditions recorded the highest mean values of plant weight, root weight and root length in both seasons. This increase in these traits may be due to suitable conditions in Nubaria as compared with Sabahia conditions. These results are in confirmed with those obtained by Nasr and Abd El-Razek (2008) and Hozayn et al. (2013).

Results pointed that the ten sugar varieties differed in plant weight $(\mathrm{g})$ only in the first season, and root weight $(\mathrm{g}) /$ plant and root length $(\mathrm{cm})$ only in the second one. Whereas, the variety (Pyramidia) recoded the highest value of plant weight and root weight in gram, while the variety (Matros) gave the longest root length during both seasons. The differences among sugar beet varieties under study could be due to the variation in the genes make up and their response to the environmental condition. The differences among sugar beet varieties were found by El-Sheikh et al. (2009), Enan et al. (2009), Hozayn et al. (2013) and Mohamed and Yasin (2013). However, Ismail (2002) indicated that root length and root diameter were not significantly different between sugar beet varieties.

Results in the same Table cleared that the interaction between Nubaria region and sugar beet variety Mammut and variety Pyramidia resulted a high significant effect on plant weight during both seasons, respectively but the highest values of root weight recorded with variety Pyramidia and Mammut under Nubaria conditions, while sowing sugar beet variety (Puma) under Nubaria condition recoded the longest roots followed by variety Mammut and Matros in the second season. On the other hand, sowing variety Gazella under Sabahia conditions gave the lowest mean values of plant and root weights in both seasons. While, the shortest roots were obtained with planting variety Heba under Sabahia region in the second season. 
Table (4). Plant attributes of sugar beet varieties as affected by Sabahia and Nubaria region conditions in both seasons

\begin{tabular}{|c|c|c|c|c|c|c|c|c|c|c|c|c|c|}
\hline \multirow[b]{2}{*}{ Characters } & \multirow[b]{2}{*}{ Varieties } & \multicolumn{2}{|c|}{$2016 / 2017$} & \multirow[b]{2}{*}{ Average } & \multicolumn{3}{|c|}{ LSD at 0.05} & \multicolumn{2}{|c|}{$2017 / 2018$} & \multirow[b]{2}{*}{ Average } & \multicolumn{3}{|c|}{ LSD at 0.05} \\
\hline & & Sabahia & Nubaria & & $\begin{array}{l}\text { Location } \\
\text { (A) }\end{array}$ & $\begin{array}{c}\text { Varieties } \\
\text { (B) }\end{array}$ & $A \times B$ & Sabahia & Nubaria & & $\begin{array}{c}\text { Location } \\
\text { (A) }\end{array}$ & $\begin{array}{c}\text { Varieties } \\
\text { (B) }\end{array}$ & $A \times B$ \\
\hline \multirow{10}{*}{$\begin{array}{c}\text { Plant } \\
\text { weight }(\mathrm{g})\end{array}$} & Charelston & 1050.0 & 1603.3 & 1326.7 & \multirow{10}{*}{131.9} & \multirow{10}{*}{89.4} & \multirow{10}{*}{126.5} & 1150.0 & 1533.3 & 1341.7 & \multirow{10}{*}{ ns } & \multirow{10}{*}{161.2} & \multirow{10}{*}{228.2} \\
\hline & Gazella & 733.3 & 1266.7 & 1000.0 & & & & 1050.0 & 1350.0 & 1200.0 & & & \\
\hline & Heba & 1500.0 & 1266.7 & 1383.3 & & & & 1500.0 & 1366.7 & 1433.3 & & & \\
\hline & Lilly & 800.0 & 1306.7 & 1053.3 & & & & 1100.0 & 1316.7 & 1208.3 & & & \\
\hline & Mammut & 1183.3 & 1741.7 & 1462.5 & & & & 1266.7 & 1733.3 & 1500.0 & & & \\
\hline & Matros & 1323.3 & 1370.0 & 1346.7 & & & & 1346.7 & 1256.7 & 1301.7 & & & \\
\hline & Nancy & 1033.3 & 1183.3 & 1108.3 & & & & 1550.0 & 1333.3 & 1441.7 & & & \\
\hline & Oscarpoly & 1416.7 & 1100.0 & 1258.3 & & & & 1516.7 & 1433.3 & 1475.0 & & & \\
\hline & Puma & 1300.0 & 1306.7 & 1303.3 & & & & 1366.7 & 1333.3 & 1350.0 & & & \\
\hline & Pyramidia & 1566.7 & 1700.0 & 1633.3 & & & & 1550.0 & 1750.0 & 1650.0 & & & \\
\hline \multicolumn{2}{|c|}{ Average $(\mathrm{B})$} & 1190.7 & 1384.5 & & & & & 1339.7 & 1440.7 & & & & \\
\hline \multirow{10}{*}{$\begin{array}{c}\text { Root } \\
\text { weight }(\mathrm{g})\end{array}$} & Charelston & 716.7 & 816.7 & 766.7 & \multirow{10}{*}{ ns } & \multirow{10}{*}{91.5} & \multirow{10}{*}{129.5} & 800.0 & 843.3 & 821.7 & \multirow{10}{*}{84.4} & \multirow{10}{*}{27.3} & \multirow{10}{*}{119.5} \\
\hline & Gazella & 483.3 & 883.3 & 683.3 & & & & 683.3 & 870.0 & 776.7 & & & \\
\hline & Heba & 1100.0 & 966.7 & 1033.3 & & & & 850.0 & 850.0 & 850.0 & & & \\
\hline & Lilly & 583.3 & 783.3 & 683.3 & & & & 750.0 & 833.3 & 791.7 & & & \\
\hline & Mammut & 800.0 & 1066.7 & 933.3 & & & & 843.3 & 1000.0 & 921.7 & & & \\
\hline & Matros & 738.3 & 876.7 & 807.5 & & & & 783.3 & 820.0 & 801.7 & & & \\
\hline & Nancy & 550.0 & 850.0 & 700.0 & & & & 833.3 & 733.3 & 783.3 & & & \\
\hline & Oscarpoly & 983.3 & 750.0 & 866.7 & & & & 800.0 & 766.7 & 783.3 & & & \\
\hline & Puma & 816.7 & 766.7 & 791.7 & & & & 870.0 & 816.7 & 843.3 & & & \\
\hline & Pyramidia & 1216.7 & 1283.3 & 1250.0 & & & & 900.0 & 966.7 & 933.3 & & & \\
\hline \multicolumn{2}{|c|}{ Average (B) } & 798.8 & 904.3 & & & & & 811.3 & 850.0 & & & & \\
\hline \multirow{10}{*}{$\begin{array}{l}\text { Root length } \\
\qquad(\mathrm{cm})\end{array}$} & Charelston & 22.0 & 27.0 & 24.5 & & & & 28.3 & 28.3 & 28.3 & & & \\
\hline & Gazella & 30.0 & 32.3 & 31.2 & & & & 30.3 & 30.7 & 30.5 & & & \\
\hline & Heba & 21.3 & 18.3 & 19.8 & & & & 21.3 & 22.0 & 21.7 & & & \\
\hline & Lilly & 19.3 & 33.3 & 26.3 & & & & 24.0 & 27.7 & 25.8 & & & \\
\hline & Mammut & 21.3 & 30.0 & 25.7 & ns & ns & ns & 26.3 & 32.7 & 29.5 & 0.9 & 2.3 & 3.2 \\
\hline & Matros & 31.0 & 36.3 & 33.7 & & & & 36.7 & 32.7 & 34.7 & & & \\
\hline & Nancy & 21.3 & 22.3 & 21.8 & & & & 24.3 & 21.0 & 22.7 & & & \\
\hline & Oscarpoly & 20.7 & 23.3 & 22.0 & & & & 24.7 & 22.7 & 23.7 & & & \\
\hline & Puma & 24.7 & 33.0 & 28.8 & & & & 27.0 & 34.3 & 30.7 & & & \\
\hline & Pyramidia & 22.3 & 21.3 & 21.8 & & & & 22.7 & 22.7 & 22.7 & & & \\
\hline Avera & ge (B) & 23.4 & 27.7 & & & & & 26.6 & 27.5 & & & & \\
\hline
\end{tabular}

ns: not significant at 0.05 level of probability. 
Table (5) revealed the effect of sugar beet varieties, locations and their interaction on root diameter $(\mathrm{cm})$, root yield $(\mathrm{t} / \mathrm{fed})$ and top yield $(\mathrm{t} / \mathrm{fed})$ during 2016/2017 and 2017/2018 seasons.

In regarding to effect of the two locations, the results showed that there was no significant difference between sowing sugar beet under Sabahia or Nubaria conditions on root diameter $(\mathrm{cm})$, root yield $(\mathrm{t} / \mathrm{fed})$ and top yield $(\mathrm{t} / \mathrm{fed})$.

The obtained results shown in Table (5) indicated that the ten sugar varieties differed in root diameter $(\mathrm{cm})$, root yield $(\mathrm{t} / \mathrm{fed})$ and top yield $(\mathrm{t} / \mathrm{fed})$. Whereas, the variety Heba recoded the highest value of root diameter (13.2 $\mathrm{cm}$ ) in the first season but variety Charelston gave the highest root diameter (12.0) in the second season. On the other side, variety Oscarpoly recorded the highest root yield (20.3 and $20.9 \mathrm{t} / \mathrm{fed}$ ) in the two seasons, respectively. Meanwhile, variety Pyramidia variety gave the highest top root (5.8 and 5.4 $\mathrm{t} / \mathrm{fed}$ ) during both seasons, respectively. The differences among sugar beet varieties under study could be due to the variation in the genetic make-up and their response to the environmental condition. The differences among sugar beet varieties were found by El-Sheikh et al. (2009), Enan et al. (2009), Hozayn et al. (2013) and Mohamed and Yasin (2013).

The results cleared that the interaction between Sabahia location and sugar beet variety Oscarpoly resulted a high significant effect on root diameter $(14.3$ and $13.0 \mathrm{~cm})$ during both seasons, respectively as shown in Figures (1 and 2) but the highest values of top yield (21.3 and $21.5 \mathrm{t} / \mathrm{fed})$ recorded with sowing V3 under Nubaria conditions, respectively in the two seasons (Figures 3 and 4). Meanwhile, sowing sugar beet variety Pyramidia under Sabahia condition recoded the heaviest top yield (6.5 and $5.5 \mathrm{t} / \mathrm{fed})$ in the first and the second seasons, respectively. 
J. Adv. Agric. Res. (Fac. Agric. Saba Basha)

Table (5). Plant attributes of sugar beet varieties as affected by Sabahia and Nubaria region conditions in both seasons

\begin{tabular}{|c|c|c|c|c|c|c|c|c|c|c|c|c|c|}
\hline \multirow[b]{2}{*}{ Characters } & \multirow[b]{2}{*}{ Varieties } & \multicolumn{2}{|c|}{$2016 / 2017$} & \multirow[b]{2}{*}{ Average } & \multicolumn{3}{|c|}{ LSD at 0.05} & \multicolumn{2}{|c|}{$2017 / 2018$} & \multirow[b]{2}{*}{ Average } & \multicolumn{3}{|c|}{ LSD at 0.05} \\
\hline & & Sabahia & Nubaria & & $\begin{array}{l}\text { Location } \\
\text { (A) }\end{array}$ & $\begin{array}{l}\text { Varieties } \\
\text { (B) }\end{array}$ & $A \times B$ & Sabahia & Nubaria & & $\begin{array}{l}\text { Location } \\
\text { (A) }\end{array}$ & $\begin{array}{l}\text { Varieties } \\
\text { (B) }\end{array}$ & $A \times B$ \\
\hline \multirow{10}{*}{$\begin{array}{c}\text { Root } \\
\text { diameter }(\mathrm{cm})\end{array}$} & Charelston & 13.0 & 12.7 & 12.8 & \multirow{10}{*}{ Ns } & \multirow{10}{*}{1.8} & \multirow{10}{*}{2.6} & 13.0 & 11.0 & 12.0 & \multirow{10}{*}{ ns } & \multirow{10}{*}{1.2} & \multirow{10}{*}{1.7} \\
\hline & Gazella & 11.0 & 9.3 & 10.2 & & & & 12.0 & 9.3 & 10.7 & & & \\
\hline & Heba & 13.3 & 13.0 & 13.2 & & & & 10.3 & 10.7 & 10.5 & & & \\
\hline & Lilly & 11.7 & 10.7 & 11.2 & & & & 11.0 & 10.0 & 10.5 & & & \\
\hline & Mammut & 7.7 & 11.3 & 9.5 & & & & 12.0 & 10.7 & 11.3 & & & \\
\hline & Matros & 9.0 & 7.7 & 8.3 & & & & 10.7 & 10.3 & 10.5 & & & \\
\hline & Nancy & 11.3 & 11.0 & 11.2 & & & & 10.7 & 9.7 & 10.2 & & & \\
\hline & Oscarpoly & 14.3 & 11.7 & 13.0 & & & & 13.0 & 10.3 & 11.7 & & & \\
\hline & Puma & 8.3 & 13.0 & 10.7 & & & & 9.0 & 11.3 & 10.2 & & & \\
\hline & Pyramidia & 12.0 & 11.3 & 11.7 & & & & 11.3 & 12.3 & 11.8 & & & \\
\hline \multicolumn{2}{|c|}{ Average (B) } & 11.2 & 11.2 & & \multirow{11}{*}{ Ns } & \multirow{11}{*}{1.2} & & 11.3 & 10.6 & & \multirow{11}{*}{ ns } & \multirow{11}{*}{1.1} & \multirow{11}{*}{1.5} \\
\hline \multirow{10}{*}{$\begin{array}{l}\text { Root yield } \\
\text { (t/fed) }\end{array}$} & Charelston & 16.2 & 20.2 & 18.2 & & & \multirow{10}{*}{1.7} & 17.7 & 18.5 & 18.1 & & & \\
\hline & Gazella & 17.7 & 16.7 & 17.2 & & & & 19.6 & 19.4 & 19.5 & & & \\
\hline & Heba & 21.3 & 18.7 & 20.0 & & & & 21.5 & 20.2 & 20.8 & & & \\
\hline & Lilly & 14.8 & 20.8 & 17.8 & & & & 16.6 & 20.4 & 18.5 & & & \\
\hline & Mammut & 16.7 & 19.0 & 17.8 & & & & 18.0 & 18.3 & 18.1 & & & \\
\hline & Matros & 17.9 & 20.4 & 19.2 & & & & 16.9 & 19.1 & 18.0 & & & \\
\hline & Nancy & 19.2 & 18.9 & 19.1 & & & & 21.1 & 20.2 & 20.7 & & & \\
\hline & Oscarpoly & 21.2 & 19.4 & 20.3 & & & & 21.3 & 20.5 & 20.9 & & & \\
\hline & Puma & 16.7 & 16.7 & 16.7 & & & & 18.6 & 17.6 & 18.1 & & & \\
\hline & Pyramidia & 18.5 & 18.8 & 18.6 & & & & 19.9 & 19.3 & 19.6 & & & \\
\hline Avera & e (B) & 18.0 & 19.0 & & & & & 19.1 & 19.3 & & & & \\
\hline \multirow{10}{*}{$\begin{array}{c}\text { Top yield } \\
\text { (t/fed) }\end{array}$} & Charelston & 5.7 & 5.0 & 5.4 & \multirow{11}{*}{ Ns } & & & 4.0 & 3.3 & 3.6 & & & \\
\hline & Gazella & 5.6 & 4.8 & 5.2 & & & & 4.9 & 3.2 & 4.1 & & & \\
\hline & Heba & 6.1 & 5.4 & 5.8 & & & & 5.3 & 5.2 & 5.3 & & & \\
\hline & Lilly & 5.6 & 5.8 & 5.7 & & & & 3.2 & 3.5 & 3.3 & & & \\
\hline & Mammut & 4.1 & 5.5 & 4.8 & & 0.4 & 1.2 & 4.2 & 5.0 & 4.6 & ns & 0.8 & ns \\
\hline & Matros & 4.7 & 5.1 & 4.9 & & & & 3.9 & 4.7 & 4.3 & & & \\
\hline & Nancy & 4.5 & 5.9 & 5.2 & & & & 5.3 & 4.5 & 4.9 & & & \\
\hline & Oscarpoly & 5.0 & 6.2 & 5.6 & & & & 5.1 & 4.7 & 4.9 & & & \\
\hline & Puma & 6.3 & 4.8 & 5.5 & & & & 2.8 & 3.0 & 2.9 & & & \\
\hline & Pyramidia & 6.5 & 5.1 & 5.8 & & & & 5.5 & 5.3 & 5.4 & & & \\
\hline Avera & e (B) & 5.4 & 5.4 & & & & & 4.4 & 4.2 & & & & \\
\hline
\end{tabular}

ns: not significant at 0.05 level of probability. 


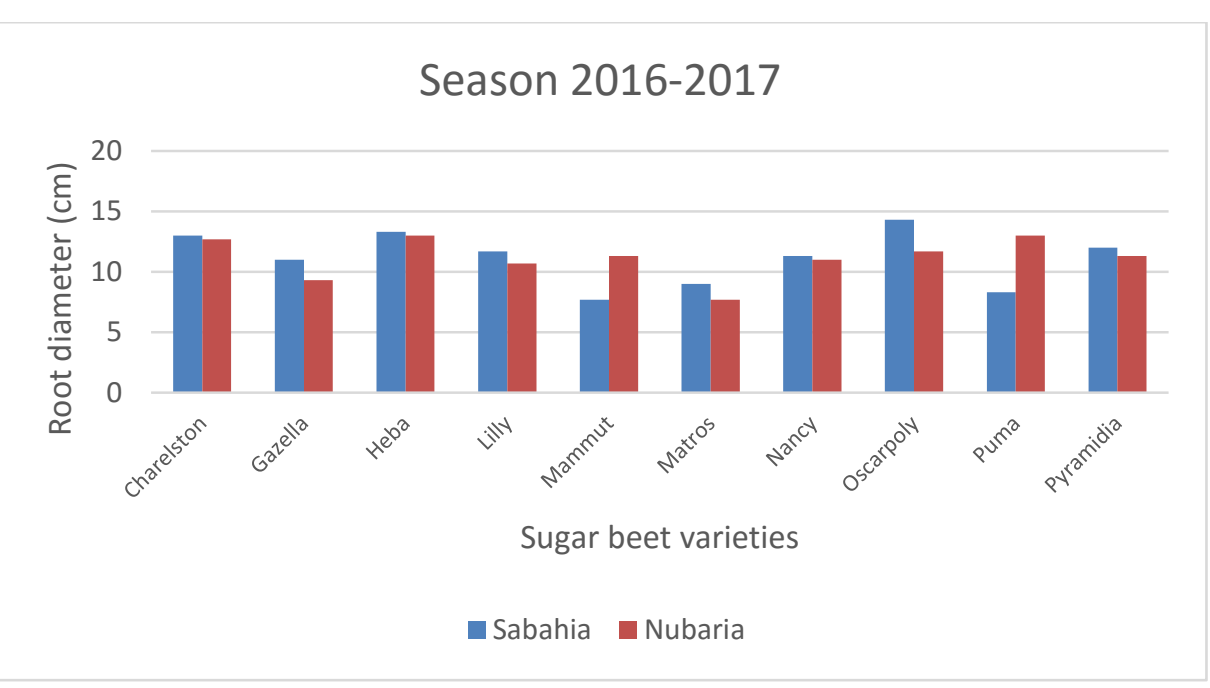

Fig. (1). Root diameter of sugar beet as affected by interaction between locations and varieties during 2016 - 2017 season.

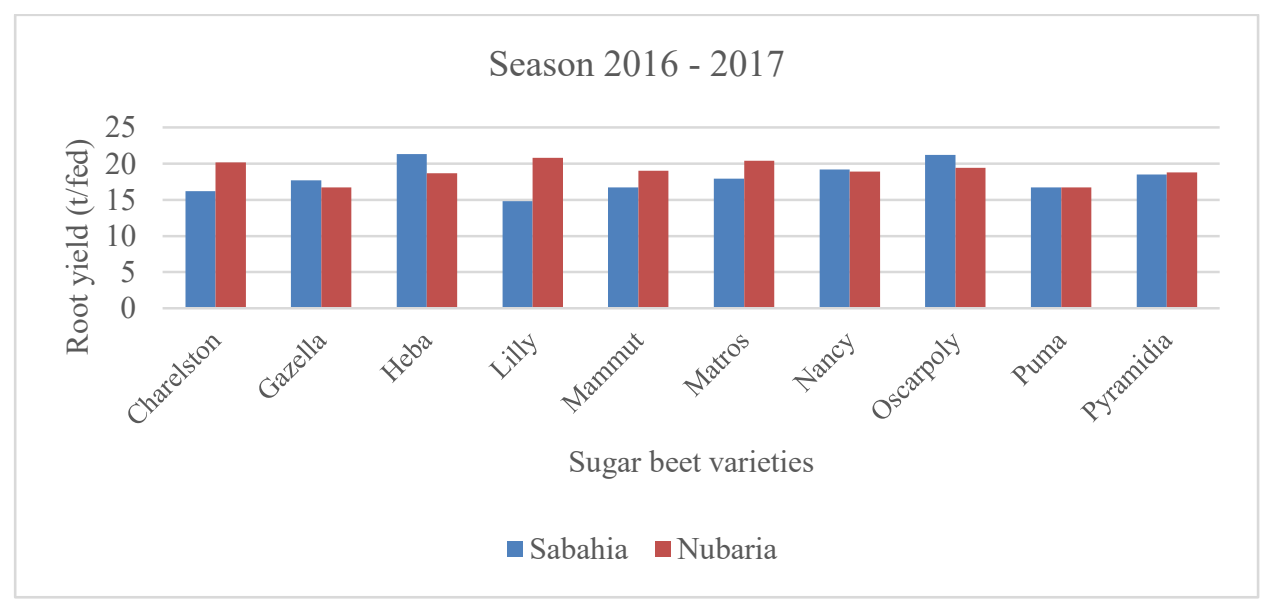

Fig. (3). Root Yield of sugar beet as affected by interaction between locations and varieties during 2016 - 2017 season.
Season 2017-2018

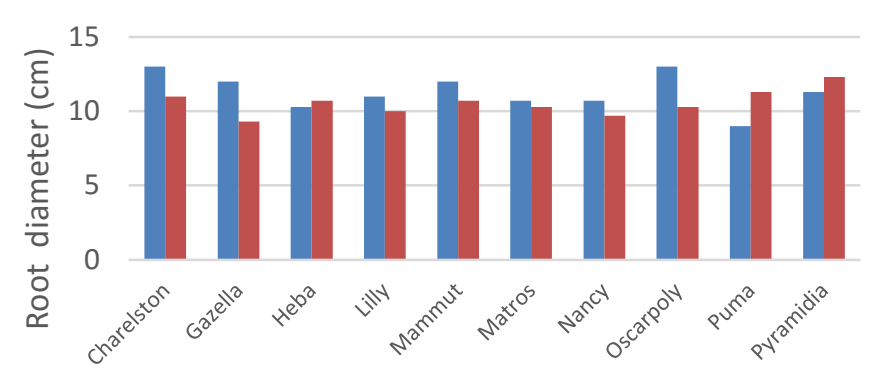

Sugar beet varieties

Sabahia Nubaria

Fig. (2). Root diameter of sugar beet as affected by interaction between locations and varieties during 2017 2018 season.

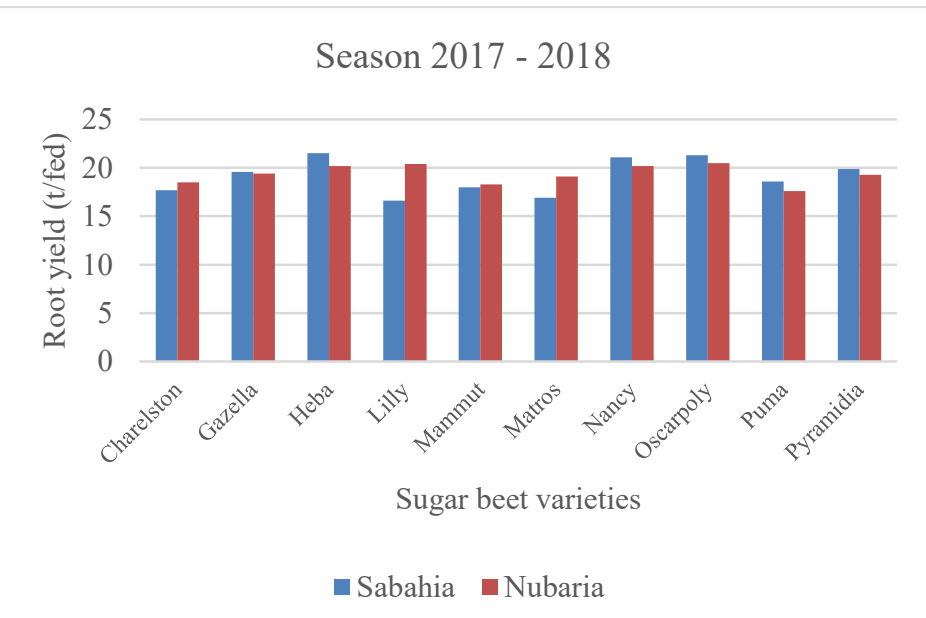

Fig. (4). Root Yield of sugar beet as affected by interaction between locations and varieties during 2017 -2018 season. 
Results in Table (6) indicate the effect of sugar beet varieties, locations and their interaction on sugar yield (t/fed), TSS (\%) and sucrose (\%) during 2016/2017 and 2017/2018 seasons.

In regard to the effect of the two locations, the results in Table (6) showed that there was no significant difference between sowing sugar beet under Sabahia or Nubaria conditions on sugar yield (t/fed), TSS (\%) in both seasons but sucrose (\%) in the first season, only. Where, sowing sugar beet under Sabahia location gave the highest sucrose (\%) in the second seasons. These results are in harmony with those obtained by Nasr and Abd El-Razek (2008).

The results shown in Table (6) indicated that the ten sugar beet varieties differed significantly in sugar yield, TSS (\%) and sucrose (\%) in both seasons. Whereas, the variety Puma recoded the highest value of sugar yield in the first and the second seasons. On the other wise, variety Pyramidia and variety Oscarpoly gave the highest TSS during both seasons, respectively. On the other side, variety Nancy recorded the highest sucrose in the two seasons. The differences among sugar beet varieties under study could be due to the variation in the genes make up and their response to the environmental condition. The differences among sugar beet varieties were found by Nasr and Abd El-Razek (2008), El-Sheikh et al. (2009), Enan et al. (2009), Hozayn et al. (2013) and Mohamed and Yasin (2013).

The same Table cleared that the interaction between Sabahia and Nubaria location with sugar beet variety Puma resulted a high significant effect on sugar yield during both seasons. However, the highest values of TSS (\%) were observed with sowing variety Oscarpoly under Nubaria conditions, respectively in the two seasons. Meanwhile, sowing sugar beet variety Nancy under Nubaria in the first season and under Sabahia condition recorded the heaviest sucrose (\%). 
Table (6). Plant attributes of sugar beet varieties as affected by Sabahia and Nubaria region conditions in both seasons

\begin{tabular}{|c|c|c|c|c|c|c|c|c|c|c|c|c|c|}
\hline \multirow[b]{2}{*}{ Characters } & \multirow[b]{2}{*}{ Varieties } & \multicolumn{2}{|c|}{$2016 / 2017$} & \multirow[b]{2}{*}{ Average } & \multicolumn{3}{|c|}{ LSD at 0.05} & \multicolumn{2}{|c|}{$2017 / 2018$} & \multirow[b]{2}{*}{ Average } & \multicolumn{3}{|c|}{ LSD at 0.05} \\
\hline & & Sabahia & Nubaria & & $\begin{array}{l}\text { Location } \\
\text { (A) }\end{array}$ & $\begin{array}{c}\text { Varieties } \\
\text { (B) }\end{array}$ & $A \times B$ & Sabahia & Nubaria & & $\begin{array}{l}\text { Location } \\
\text { (A) }\end{array}$ & $\begin{array}{l}\text { Varieties } \\
\text { (B) }\end{array}$ & $A \times B$ \\
\hline \multirow{10}{*}{$\begin{array}{l}\text { Sugar yield } \\
\text { (t/fed) }\end{array}$} & Charelston & 2.8 & 3.4 & 3.1 & \multirow{10}{*}{ ns } & \multirow{10}{*}{0.5} & \multirow{10}{*}{ ns } & 2.4 & 3.1 & 2.8 & \multirow{10}{*}{ ns } & \multirow{10}{*}{0.3} & \multirow{10}{*}{0.5} \\
\hline & Gazella & 3.0 & 3.1 & 3.0 & & & & 2.7 & 3.4 & 3.0 & & & \\
\hline & Heba & 3.2 & 3.2 & 3.2 & & & & 3.4 & 4.2 & 3.8 & & & \\
\hline & Lilly & 3.6 & 3.1 & 3.3 & & & & 3.3 & 2.8 & 3.1 & & & \\
\hline & Mammut & 3.1 & 3.2 & 3.2 & & & & 3.1 & 3.4 & 3.2 & & & \\
\hline & Matros & 3.2 & 2.9 & 3.1 & & & & 2.8 & 3.1 & 2.9 & & & \\
\hline & Nancy & 3.9 & 3.6 & 3.8 & & & & 3.1 & 3.5 & 3.3 & & & \\
\hline & Oscarpoly & 3.1 & 3.1 & 3.1 & & & & 3.9 & 4.2 & 4.1 & & & \\
\hline & Puma & 3.4 & 4.2 & 3.8 & & & & 5.0 & 4.3 & 4.6 & & & \\
\hline & Pyramidia & 3.0 & 3.1 & 3.1 & & & & 3.8 & 3.4 & 3.6 & & & \\
\hline \multicolumn{2}{|c|}{ Average $(B)$} & 3.2 & 3.3 & & \multirow{11}{*}{ ns } & \multirow{11}{*}{1.1} & \multirow{11}{*}{1.5} & 3.4 & 3.5 & & \multirow{11}{*}{ ns } & \multirow{11}{*}{1.0} & \multirow{11}{*}{1.4} \\
\hline \multirow{10}{*}{ TSS (\%) } & Charelston & 23.3 & 21.0 & 22.2 & & & & 26.0 & 24.0 & 25.0 & & & \\
\hline & Gazella & 23.0 & 21.0 & 22.0 & & & & 25.0 & 24.0 & 24.5 & & & \\
\hline & Heba & 26.3 & 25.3 & 25.8 & & & & 23.3 & 24.7 & 24.0 & & & \\
\hline & Lilly & 24.7 & 20.0 & 22.3 & & & & 22.0 & 22.7 & 22.3 & & & \\
\hline & Mammut & 23.3 & 21.7 & 22.5 & & & & 22.3 & 24.7 & 23.5 & & & \\
\hline & Matros & 23.7 & 21.7 & 22.7 & & & & 23.7 & 23.0 & 23.3 & & & \\
\hline & Nancy & 23.7 & 25.3 & 24.5 & & & & 23.7 & 24.0 & 23.8 & & & \\
\hline & Oscarpoly & 24.7 & 27.3 & 26.0 & & & & 24.3 & 25.0 & 24.7 & & & \\
\hline & Puma & 22.0 & 20.0 & 21.0 & & & & 22.7 & 24.0 & 23.3 & & & \\
\hline & Pyramidia & 26.3 & 26.7 & 26.5 & & & & 24.0 & 23.7 & 23.8 & & & \\
\hline \multicolumn{2}{|c|}{ Average $(\mathrm{B})$} & 24.1 & 23.0 & & & & & 23.7 & 24.0 & & & & \\
\hline \multirow{10}{*}{$\begin{array}{c}\text { Sucrose } \\
(\%)\end{array}$} & Charelston & 16.7 & 15.7 & 16.2 & & & & 18.0 & 17.2 & 17.6 & & & \\
\hline & Gazella & 17.3 & 17.5 & 17.4 & & & & 17.5 & 17.2 & 17.3 & & & \\
\hline & Heba & 19.3 & 17.3 & 18.3 & & & & 20.0 & 18.3 & 19.2 & & & \\
\hline & Lilly & 17.3 & 16.3 & 16.8 & & & & 17.0 & 16.8 & 16.9 & & & \\
\hline & Mammut & 16.7 & 16.2 & 16.4 & ns & 1.4 & ns & 16.5 & 17.3 & 16.9 & 0.3 & 0.8 & 1.2 \\
\hline & Matros & 16.8 & 16.2 & 16.5 & & & & 16.8 & 16.8 & 16.8 & & & \\
\hline & Nancy & 18.7 & 20.7 & 19.7 & & & & 21.0 & 20.0 & 20.5 & & & \\
\hline & Oscarpoly & 19.0 & 19.0 & 19.0 & & & & 19.0 & 19.7 & 19.3 & & & \\
\hline & Puma & 16.3 & 16.0 & 16.2 & & & & 17.7 & 17.7 & 17.7 & & & \\
\hline & Pyramidia & 19.0 & 18.0 & 18.5 & & & & 21.0 & 18.7 & 19.8 & & & \\
\hline Aver & ge (B) & 17.7 & 17.3 & & & & & 18.5 & 18.0 & & & & \\
\hline
\end{tabular}




\section{CONCLUSION}

The results from this study revealed that one of these varieties i.e. Pyramidia, Puma and Oscarpoly can be planted under Nubaria and Sabahia region for getting the highest yield, yield components and quality of sugar beet crop.

\section{REFERENCES}

AOAC. (1995). Association of Official Analytical Chemists. Official methods of analysis, $16^{\text {th }}$ edition, AOAC International, Washington, DC.

Ahmad, S. and R. Awais (2011). Evaluation of sugar beet varieties for their adaptability in different soil and environmental conditions of Punjab. Final Report (2008-11) Agric. Linkages Program (ALP), National Agric. Res. Cen., Islamabad, Pakistan.

Chapman, H.D. and R.F. Pratt (1978). Methods analysis for soil, plant and water. Univ. of California Div. Agric. Sci., 16-38.

CoStat, Ver. 6.4 (2005). Cohort software798 light house Ave. PMB320, Monterey, CA93940, and USA. email: info@cohort.com and Website: http://www.cohort.com/DownloadCoStatPart2.html

FAO (2016). Food Agric. Organization. www.fao.org/faostat/en/\#data.

El- Sheikh, S. R. E., Khaled, K. A. M. and Enan, S. A. A. M. (2009). Evaluation of some sugar beet varieties under three harvesting dates. J. Agric. Sci. Mansoura Univ. 34 (3), 1559-1567.

Enan, S. A. A. M., S. R. E. El- Sheikh and K. A. M. Khaled (2009). Evaluation of some sugar beet varieties under different levels of $\mathrm{N}$ and Mo fertilization. J. Biol. Chem. Environ. Sci., 4 (1), 345-362.

Gobarah, M.E. and B.B. Mekki (2005). Influence of boron application on yield and juice quality of some sugar beet cultivars grown under saline soil conditions. J. Appl. Sci. Res.,1(5): 373-379.

Gomez, K.N. and A.A. Gomez (1984). Statistical procedures for agricultural research. John Wiley and Sons, New York, 2nd ed., 68 P.

Hozayn, M., A.A. Abd El-Monem and A.A. Bakery (2013). Screening of some exotic sugar beet cultivars grown under newly reclaimed sandy soil for yield and sugar quality traits. J. Appl. Sci. Res., 9(3): 2213-2222.

Ismail, A.M.A (2002). Evaluation of some sugar beet varieties under different nitrogen levels in El-Fayium Egypt. J. Appl. Sci., 17: 75-85.

Khan, D., I. Khan, P. Khan and G. Rehman (2004). Sugar beet cultivation in the southern parts of NWFP. Pakistan Sugar J., 19: 19-24.

Korayem, A.M., H.M.S. El-Bassiouny, A.A. Abd El-Monem and M.M.M. Mohamed (2012). Physiological and biochemical changes in different sugar beet genotypes infected with root-knot nematode. Acta Physiologia Plantaram, 34: 1847-1861.

Mohamed, H. Y. and M.A.T. Yasin (2013). Response of some sugar beet varieties to harvesting dates and foliar application of boron and zinc in sandy soils. Egypt. J. Agron., 35(2):227- 252. 
Nasr, M.I. and A.M. Abd El-Razek (2008). Sugar beet performance under newly reclaimed soil conditions of Sinai, Egypt. Sugar Technology, 10(3): 210218.

الملخص العريي

\section{ثقيم بعض أصناف بنجر السكر تحث ظروف منطقتي الصبحية والتويارية}

$$
\begin{aligned}
& \text { عمرو محمد الشيخ' - نادية كامل الصافي ' - حسام محمد الشرنويب } \\
& \text { ' قسم بحوث التربية والوراثة - معهد بحوث المحاصيل السكرية - مركز البحوث الزراعية - مصر } \\
& \text { ؟ قسم بحوث الفسيولوجي والكيمياء - معهد بحوث المحاصيل السكرية - مركز البحوث الزراعية - } \\
& \text { مصر }
\end{aligned}
$$

أجريت تجربتان حقليتان في مزرعتي محطتي بحوث النوباريـة بـالبحيرة والصبحية بالإسكندرية خـلال موسمي

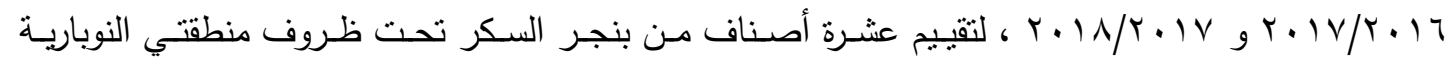
والصبحية. وزعت المعاملات في تصميم القطع المنشقة مرة واحدة ، حيث كانت منطقتي الزراعة هي القطع ونع الرئيسية ، وكانت أصناف البنجر هي القطع الثقية في ثلاثة مكررات والأصناف هي:

(Charelston, Gazella, Heba, Lilly, Mammut, Matros, Nancy, Oscarpoly, Puma, and وتم زراعة العشرة أصناف من بنجر السكر في 9 و r ا أكتوبر خلال الموسم الأول والثاني علي التوالي وتمت الزراعة علي خطوط بعرض • 7 سم علي ريشة واحدة والمسافة بين الجور مب سم - وتحتوي كل قطعة

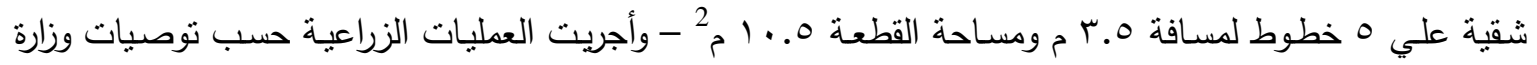

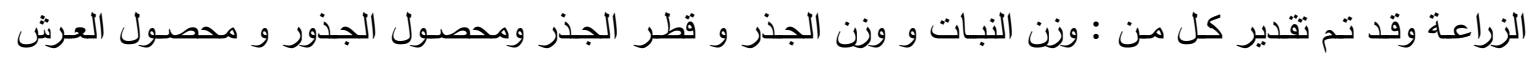

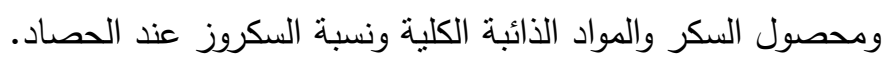

أنثارت النتائج المتحصل عليها الي وجود اختلافات معنوية بين منطقتي الدراسة (النوبارية والصبحية) في صفات المحصول ومكوناته لمحصول بنجر السكر ، وأيضاً اختلفت الأصناف فيما بينها في معظم صفات المحصول ومكوناته وصفات الجودة.

أوضحت النتائج أن هناك تأثثير معنوي للتداخل بين موقعي الزراعة والأصناف حيث وجد أن زراعة هذه الأصناف لبنجر السكر منل أوسكار بولي و بوما وبيراميديا تحت ایى من ظروف منطقة النوبارية أو الصبحية حقق أعلى قيم للصفات المحصولية وصفات الجودة خلال موسمي الدراسة.

وتوصي هذه الدراسة بزراعة أصناف من بنجر السكر وهي بيراميديا وبوما وأوسكاربولي تحت ظروف منطقة الصبحية أو النوبارية واستخدامها في عملية التربية لتحسين الصفات وزيادة المحصول ونئ وجودنئه 
J. Adv. Agric. Res. (Fac. Agric. Saba Basha) 